\title{
SS and CODremoval in Artificial Stone Wastewater Using Coagulation Process
}

\author{
Ping ZHANG* \\ Collaborative Innovation Center for Water Pollution \\ Control and Water Safety in Karst Area \\ Guilin University of Technology \\ Guilin 541004, China \\ e-mail: 497474987@qq.com,www.glut.edu.cn \\ Qi-meng ZHANG \\ Collaborative Innovation Center for Water Pollution \\ Control and Water Safety in Karst Area \\ Guilin University of Technology \\ Guilin 541004, China \\ Qing-lin XIE \\ Collaborative Innovation Center for Water Pollution \\ Control and Water Safety in Karst Area \\ Guilin University of Technology \\ Guilin 541004, China
}

\author{
Lin-feng CHEN \\ Collaborative Innovation Center for Water Pollution \\ Control and Water Safety in Karst Area \\ Guilin University of Technology \\ Guilin 541004, China
}

\author{
Sheng-min WANG \\ Collaborative Innovation Center for Water Pollution \\ Control and Water Safety in Karst Area \\ Guilin University of Technology \\ Guilin 541004, China
}

\begin{abstract}
Nan-chun CHEN
College of Materials Science and Engineering and Ministry-province Jointly-constructed Base for State Key Laboratory of Processing for Nonferrous Metals and Featured Materials

Guilin University of Technology

Guilin, 541004, China

e-mail: cnc@glut.edu.cn
\end{abstract}

\begin{abstract}
The obvious features of artificial stone wastewater are high SS and COD concentration, and the wastewater cannot meet the discharge standard. Three-stage coagulation procedure was adopted to dispose wastewater by controlling the different coagulants, coagulant dosage and $\mathrm{pH}$ value in this study. The results showed that aluminum sulfate was acted as coagulant and the dosages were $56.70 \mathrm{mg} / \mathrm{L}, 16.00 \mathrm{mg} / \mathrm{L}$ and $7.50 \mathrm{mg} / \mathrm{L}$ respectively in the three-stage coagulation procedure, the supernatant $\mathrm{SS}$ of wastewater was $8.8 \mathrm{mg} / \mathrm{L}$, the turbidity was 6.9 NTU and COD was $73.65 \mathrm{mg} / \mathrm{L}$. Based on the threestage coagulation procedure, the supernatant was further to be adsorbed by diatomite. When the $\mathrm{pH}$ was 6.40 , the dosage was $20 \mathrm{~g} / \mathrm{L}$, and the supernatant COD was $16.80 \mathrm{mg} / \mathrm{L}$, the supernatant, treated by three-stage coagulation procedure, can be directly used for production.
\end{abstract}

Keywords-Artificial stone processing wastewater; SS and COD; Coagulation; Adsorb Introduction.

\section{INTRODUCTION}

The main pollutants of artificial stone processing wastewater were SS and COD. It was result from stone powder came from stone cutting and edging, and the residues of auxiliary raw material, used for processing, such as resin adhesive, curing agent and so on Powder in the water showed the state of suspended and colloidal, the concentration of SS was $1000 \mathrm{mg} / \mathrm{L}$ or more[1-3]. The main components of residues were resin acids and their saponification products, unsaturated fatty acids and their saponification products, lignin and their degradation products, etc. At present, only part of SS can be removed by coagulation and sedimentation [4-9].

\section{MATERIAL AND METHODS}

Wastewater from Guangxi Li Sheng Stone Industry Co., Ltd., the water property was present in table 1.

TABLE I. THE WATER QUALITY OF ARTIFICIAL STONE PROCESSING WASTEWATER

\begin{tabular}{llll}
\hline index & $\mathrm{SS}(\mathrm{mg} / \mathrm{L})$ & Turbidity(NTU) & $\mathrm{COD}(\mathrm{mg} / \mathrm{L})$ \\
\hline value & 1688 & 1145 & 8640 \\
\hline
\end{tabular}

Three Coagulants, aluminum sulfate, poly aluminum, ferric chloride, were used in the experiment. The coagulant was prepared into $10 \mathrm{~g} / \mathrm{L}$ solution.

The first coagulation: $600 \mathrm{~mL}$ wastewater was took into a $1000 \mathrm{~mL}$ stirring cup, the wastewater was adjusted to a $\mathrm{pH}$ value, a certain amount of coagulation was added into the stirring cup and stirred with six-unit coagulant mixer. The process of six-unit coagulant mixer: the first stage, stirred for $30 \mathrm{~s}$, with a speed of $300 \mathrm{r} / \mathrm{min}$; the second stage, stirred for $3 \mathrm{~min}$, and the stirring speed was $150 \mathrm{r} / \mathrm{min}$; the third stage, stirred for $5 \mathrm{~min}$, the speed was $150 \mathrm{r} / \mathrm{min}$. After then rest for 20min, the supernatant was taken and the COD, SS and turbidity were measured.

The second coagulation: $500 \mathrm{~mL}$ supernatant of the first coagulation was added into a $1000 \mathrm{~mL}$ stirring cup, and then dispose the supernatant with the same as the first coagulation 
stirring process, Resting for 20min after completing stir, the supernatant was taken, and then COD, SS and turbidity were measured.

The third coagulation: $400 \mathrm{~mL}$ supernatant of the second coagulation was added into a $1000 \mathrm{~mL}$ stirring cup, adjusted the $\mathrm{pH}$ value, added in a certain amount of coagulation and stirred with six-unit coagulant mixer with the same as the first coagulation stirring process, Resting for 20min after completing stir. Finally, the COD, SS and turbidity were measured in the supernatant. Absorption: $50 \mathrm{~mL}$ supernatant of the third coagulation was injected into $100 \mathrm{~mL}$ centrifuge tube, and different dosage diatomite was added into the centrifuge tubes respectively. The supernatant was adjusted to a $\mathrm{pH}$ value. After then oscillating the tubes with Constant water bath panoscillating for $6 \mathrm{~h}$, Centrifuged the sample with a speed of $4000 \mathrm{r} / \mathrm{min}$ for $5 \mathrm{~min}$, then COD in the supernatant was measured.

COD was measured by dichromate digestion in a Microwave Oven with ECH- II microwave heater; SS was tested by weight method with WSZ-100 and WSZ-800 turbidity meter; the $\mathrm{pH}$ value was measured with a UB-7 $\mathrm{pH}$ meter; the coagulation experiment was carried out with a ZR4-6 type six-blending coagulator.

\section{RESULTS AND DISCUSSION}

\section{A. The Effect of Different Coagulants on COD and SS}

Aluminum sulfate, poly aluminum chloride, ferric chloride were selected as coagulant, the wastewater was adjusted to the different $\mathrm{pH}$ values, the dosage of three coagulants was $83.33 \mathrm{mg} / \mathrm{L}$ (table 2 to 4 )

TABLE II. COAGULATION OF ALUMINUM SULFATE WITH DIFFERENT $\mathrm{PH}$ VALUES

\begin{tabular}{lllllll}
\hline $\mathrm{pH}$ & $\begin{array}{l}\mathrm{SS} \\
(\mathrm{mg} / \mathrm{L} \\
)\end{array}$ & $\begin{array}{l}\text { Turbidit } \\
\mathrm{y}(\mathrm{mg} / \mathrm{L})\end{array}$ & $\begin{array}{l}\mathrm{COD} \\
(\mathrm{mg} / \mathrm{L})\end{array}$ & $\begin{array}{l}\text { Remova } \\
\text { SS }(\%)\end{array}$ & $\begin{array}{l}\text { Removal } \\
\text { turbidity } \\
(\%)\end{array}$ & $\begin{array}{l}\text { Remo } \\
\text { val } \\
\mathrm{COD}( \\
\%)\end{array}$ \\
\hline 5.6 & 10.2 & 35 & 6235.44 & 99.39 & 96.86 & 27.83 \\
\hline 6.4 & 10.2 & 32 & 5995.34 & 99.40 & 97.13 & 30.61 \\
\hline 6.9 & 8.2 & 25 & 5448.61 & 99.51 & 97.76 & 36.94 \\
\hline 7.6 & 8.1 & 15 & 5048.58 & 99.52 & 98.65 & 41.57 \\
\hline 8.4 & 9.2 & 21 & 5236.32 & 99.45 & 98.12 & 39.39 \\
\hline 10. & 8.5 & 25 & 5246.86 & 99.50 & 97.76 & 39.27 \\
\hline
\end{tabular}

With the increasing of $\mathrm{pH}$ value (Table2), the removal rate of $\mathrm{COD}$ increased gradually. In addition, when the $\mathrm{pH}$ value was 7.6, the removal rate of COD was the best with the value of $41.57 \%$. However the $\mathrm{pH}$ value was range from 8 to 10 , removal rate of COD was decreased slightly. Besides, after coagulation the removal rate of SS and turbidity in wastewater both reached over $99 \%$ and $95 \%$ respectively.

Table 3 was shown that poly aluminum chloride was selected as the coagulant, with the increasing of $\mathrm{pH}$ value, the removal rate of COD increased gradually. When the $\mathrm{pH}$ value was 10.0, the removal rate of COD was the best with $37.77 \%$. The removal rate of $\mathrm{SS}$ and turbidity both reached over $99 \%$ and $95 \%$ respectively after coagulation.

That ferric chloride was selected as the coagulant, with the increasing of $\mathrm{pH}$ value, the removal rate of COD increased gradually. When the $\mathrm{pH}$ value was 10.0 , the removal rate of COD was the best, and the value was $33.65 \%$.The removal rate of SS and turbidity both can reach over $99 \%$ and $95 \%$ respectively after coagulation.

It was observed that the three coagulants can remove SS and turbidity in the wastewater efficiently. Although the removal rate value of COD was not high, $1853.44 \sim 3591.42 \mathrm{mg} / \mathrm{L}$ of COD can be removed, and the coagulation effect of aluminum sulfate was better than aluminum chloride and ferric chloride. Therefore, aluminum sulfate was the best coagulant, and its optimum $\mathrm{pH}$ was 7.6. The coagulation experiments with different dosages were made with aluminum sulfate as coagulant (Table 5).

With the increasing of dosage, the removal rate of COD was increased gradually and the best was $43.86 \%$ when the dosage was $56.7 \mathrm{mg} / \mathrm{L}$, but the removal rate declined when added the dosage continually. Thus the best dosage of coagulant was $56.7 \mathrm{mg} / \mathrm{L}$. After coagulation, the removal rate of SS can reached over $99 \%$, and the removal rate of turbidity was above $95 \%$.

Under the dosage was $56.7 \mathrm{mg} / \mathrm{L}, \mathrm{pH}=7.6$, removal rate of SS and turbidity were high. After the coagulation, SS was $8.2 \mathrm{mg} / \mathrm{L}$ and the turbidity was $16 \mathrm{NTU}$, meeting the discharge standard, but COD removal rate just was $43.86 \%$.Although the value of COD was declined from $8640.00 \mathrm{mg} / \mathrm{L}$ to $4850.21 \mathrm{mg} / \mathrm{L}$, it was still beyond the reach of discharge standard. Therefore, to proceeding the second and third coagulation on the basis of the first coagulation experiment was necessary for treatment process.

TABLE III. COAGULATION OF POLY ALUMINUM CHLORIDE WITH DIFFERENT PH VALUES

\begin{tabular}{lllllll}
\hline $\mathrm{pH}$ & $\begin{array}{l}\mathrm{SS} \\
(\mathrm{mg} / \\
\mathrm{L})\end{array}$ & $\begin{array}{l}\text { Turbidit } \\
(\mathrm{mg} / \mathrm{L})\end{array}$ & $\begin{array}{l}\text { COD } \\
(\mathrm{mg} / \mathrm{L})\end{array}$ & $\begin{array}{l}\text { Remo } \\
\text { val } \\
(\%)\end{array}$ & $\begin{array}{l}\text { Remova } \\
\text { turbidity } \\
(\%)\end{array}$ & $\begin{array}{l}\text { Removal } \\
\text { COD }(\%)\end{array}$ \\
\hline 5.6 & 10.4 & 55 & 6304.66 & 99.38 & 95.07 & 27.03 \\
\hline 6.4 & 10.2 & 43 & 6179.35 & 99.40 & 96.14 & 28.48 \\
\hline 6.9 & 8.3 & 41 & 5758.88 & 99.51 & 96.32 & 33.35 \\
\hline 7.6 & 8.3 & 35 & 5696.68 & 99.51 & 96.86 & 34.07 \\
\hline 8.4 & 9.2 & 36 & 5536.32 & 99.45 & 96.77 & 35.92 \\
\hline 10. & 8.7 & 36 & 5376.62 & 99.48 & 96.77 & 37.77 \\
\hline 0
\end{tabular}

TABLE IV. COAGULATION OF FERRIC CHLORIDE WITH DIFFERENT PH VALUES

\begin{tabular}{cllllll}
\hline $\mathrm{pH}$ & $\begin{array}{l}\mathrm{SS} \\
(\mathrm{mg} / \\
\mathrm{L})\end{array}$ & $\begin{array}{l}\text { Turbi } \\
\text { dity } \\
(\mathrm{mg} / \mathrm{L}\end{array}$ & $\begin{array}{l}\text { COD } \\
(\mathrm{mg} / \mathrm{L})\end{array}$ & $\begin{array}{l}\text { Remova } \\
\text { 1 SS }(\%)\end{array}$ & $\begin{array}{l}\text { Removal } \\
\text { turbidity( } \\
\%)\end{array}$ & $\begin{array}{l}\text { Removal } \\
\text { COD } \\
(\%)\end{array}$ \\
\hline 5.6 & 10.7 & 55 & 6786.56 & 99.37 & 95.07 & 21.45 \\
\hline 6.4 & 10.5 & 43 & 6554.87 & 99.38 & 96.14 & 24.13 \\
\hline 6.9 & 10.3 & 41 & 6223.45 & 99.39 & 96.32 & 27.97 \\
\hline 7.6 & 9.7 & 35 & 6088.66 & 99.43 & 96.86 & 29.53 \\
\hline 8.4 & 9.2 & 36 & 5936.77 & 99.45 & 96.77 & 31.29 \\
\hline 10.0 & 8.5 & 36 & 5732.46 & 99.50 & 96.77 & 33.65 \\
\hline
\end{tabular}


TABLE V. THE RESULTS OF DIFFERENT DOSAGES THAT ALUMINUM SULFATE AS COAGULANT AND THE OPTIMUM PH=7.6

\begin{tabular}{lllllll}
\hline $\begin{array}{l}\text { Dosa } \\
\text { ges } \\
(\mathrm{mg} / \\
\mathrm{L})\end{array}$ & $\begin{array}{l}\text { SS } \\
(\mathrm{mg} / \mathrm{L}\end{array}$ & $\begin{array}{l}\text { Turbi } \\
\text { dity } \\
(\mathrm{mg} / \\
\mathrm{L})\end{array}$ & $\begin{array}{l}\text { COD } \\
(\mathrm{mg} /\end{array}$ & $\begin{array}{l}\text { Removal } \\
\text { SS }(\%)\end{array}$ & $\begin{array}{l}\text { Removal } \\
\text { turbidity( } \\
\%)\end{array}$ & $\begin{array}{l}\text { Remov } \\
\text { al } \\
\text { COD( } \\
\%)\end{array}$ \\
\hline 16.7 & 10.1 & 32 & $\begin{array}{l}5732 \\
.96\end{array}$ & 99.40 & 97.13 & 33.65 \\
\hline 30.0 & 9.9 & 31 & $\begin{array}{l}5386 \\
.44\end{array}$ & 99.41 & 97.22 & 37.66 \\
\hline 43.3 & 8.5 & 23 & $\begin{array}{l}5055 \\
.34\end{array}$ & 99.50 & 97.94 & 41.49 \\
\hline 56.7 & 8.2 & 16 & $\begin{array}{l}4850 \\
.21\end{array}$ & 99.51 & 98.57 & 43.86 \\
\hline 70.0 & 9.0 & 21 & $\begin{array}{l}5046 \\
.64\end{array}$ & 99.47 & 98.12 & 41.59 \\
\hline 83.3 & 8.7 & 23 & $\begin{array}{l}5089 \\
.45\end{array}$ & 99.49 & 97.94 & 41.09 \\
\hline
\end{tabular}

\section{B. The Effects of the Second and Third Coagulation}

\section{Selecting Aluminum Sulfate as Coagulant}

The dosage of aluminum sulfate was $56.7 \mathrm{mg} / \mathrm{L}$, the first coagulation supernatant (COD was $4850.21 \mathrm{mg} / \mathrm{L}$, SS was $8.2 \mathrm{mg} / \mathrm{L}$ ) under the dosage of coagulant was $56.7 \mathrm{mg} / \mathrm{L}$ and $\mathrm{pH}=7.6$ was adjusted to the various values of $\mathrm{pH}$, and carried out the second coagulation, the results were present in table 6.Table7 was shown the experimental results on the conditions that optimum $\mathrm{pH}$ and different dosages. There were no analysis about the removal of SS and turbidity, on account of the supernatant containing the low concentration of SS and turbidity. Therefore, only the SS and turbidity values of the supernatant after second coagulation were listed.

TABLE VI. THE SECOND COAGULATION RESULTS OF DIFFERENT PH AND ALUMINUM SULFATE AS COAGULANT

\begin{tabular}{ccccc}
\hline $\mathrm{pH}$ & $\begin{array}{c}\mathrm{SS} \\
(\mathrm{mg} / \mathrm{L})\end{array}$ & $\begin{array}{c}\text { Turbidity } \\
(\mathrm{mg} / \mathrm{L})\end{array}$ & $\begin{array}{c}\text { COD } \\
(\mathrm{mg} / \mathrm{L})\end{array}$ & $\begin{array}{c}\text { Removal COD } \\
(\%)\end{array}$ \\
\hline 5.6 & 12.4 & 6.5 & 488.56 & 89.93 \\
\hline 6.4 & 10.2 & 8.0 & 496.43 & 89.76 \\
\hline 6.9 & 10.2 & 7.6 & 464.68 & 90.42 \\
\hline 7.6 & 8.9 & 7.5 & 448.35 & 90.76 \\
\hline 8.2 & 10.3 & 5.7 & 482.36 & 90.05 \\
\hline 10.2 & 9.6 & 10.5 & 472.86 & 90.25 \\
\hline
\end{tabular}

The removal efficiency of COD was the best when $\mathrm{pH}$ value was 7.6 , with the value of $90.76 \%$. The SS of the wastewater after coagulation was $8.9 \mathrm{mg} / \mathrm{L}$, the turbidity was $7.5 \mathrm{NTU}$ and the COD was $448.35 \mathrm{mg} / \mathrm{L}$.

That optimal $\mathrm{pH}$ value of 7.6, the removal rate of COD increased with the increasing of the dosages, but it increased slowly when the dosage was more than $16 \mathrm{mg} / \mathrm{L}$. Thus, from the point of view of economic, the optimum dosage was $16 \mathrm{mg} / \mathrm{L}$. After the second coagulation, the SS, turbidity and COD of supernatant were $10.4 \mathrm{mg} / \mathrm{L}, 10.1 \mathrm{NTU}$ and 462.42 $\mathrm{mg} / \mathrm{L}$ respectively. As a result of the secondary coagulation, the COD removal efficiency and the removal rate were more than $90 \%$, but the COD of effluent was $462.42 \mathrm{mg} / \mathrm{L}$, which could not meet the discharge standard. Therefore, it is essential to carry out the third coagulation based on the coagulation of previous experiment. The optimum $\mathrm{pH}$ values of the first and second coagulation were 7.6, and the third coagulation $\mathrm{pH}$ was also 7.6.During carrying out the third coagulation of different dosages (table 8).

TABLE VII. THE SECOND RESULTS OF DIFFERENT DOSAGES AND OPTIMUM PH, ALUMINUM SULFATE AS COAGULANT

\begin{tabular}{ccccc}
\hline $\begin{array}{c}\text { The dosages } \\
(\mathrm{mg} / \mathrm{L})\end{array}$ & $\begin{array}{c}\text { SS } \\
(\mathrm{mg} / \mathrm{L})\end{array}$ & $\begin{array}{c}\text { Turbidity } \\
(\mathrm{mg} / \mathrm{L})\end{array}$ & $\begin{array}{c}\text { COD } \\
(\mathrm{mg} / \mathrm{L})\end{array}$ & $\begin{array}{c}\text { Removal } \\
\text { COD } \\
(\%)\end{array}$ \\
\hline 8 & 13.6 & 10.9 & 531.98 & 89.03 \\
\hline 12 & 13.2 & 10.3 & 495.78 & 89.78 \\
\hline 14 & 12.2 & 10.3 & 488.67 & 89.92 \\
\hline 16 & 10.4 & 10.1 & 462.42 & 90.47 \\
\hline 30 & 9.8 & 10.0 & 460.15 & 90.51 \\
\hline 44 & 8.8 & 8.4 & 456.46 & 90.59 \\
\hline 56 & 8.0 & 8.2 & 450.96 & 90.70 \\
\hline 70 & 8.6 & 7.8 & 438.35 & 90.96 \\
\hline 84 & 13.0 & 10.2 & 446.36 & 90.80 \\
\hline
\end{tabular}

That optimal $\mathrm{pH}$ value of 7.6 , the COD removal rate increased with the increasing of the dosages. The dosage of $7.5 \mathrm{mg} / \mathrm{L}$ was the best, however the dosage increased continually, the removal rate of COD was decreased, so the optimum dosage was $7.5 \mathrm{mg} / \mathrm{L}$. After the third coagulation, SS was $8.8 \mathrm{mg} / \mathrm{L}$, turbidity was $6.9 \mathrm{NTU}$, and COD was $73.65 \mathrm{mg} / \mathrm{L}$. It could meet the Integrated Wastewater Discharge Standard. The removal rate of SS, turbidity and COD was $99.48 \%, 99.38 \%$ and $99.15 \%$ respectively.

TABLE VIII. THE THIRD RESULTS OF DIFFERENT DOSAGES AND OPTIMUM PH, ALUMINUM SULFATE AS COAGULANT

\begin{tabular}{ccccc}
\hline $\begin{array}{c}\text { The } \\
\text { dosages } \\
(\mathrm{mg} / \mathrm{L})\end{array}$ & $\begin{array}{c}\text { SS } \\
(\mathrm{mg} / \mathrm{L})\end{array}$ & $\begin{array}{c}\text { Turbidi } \\
\text { ty } \\
(\mathrm{mg} / \mathrm{L})\end{array}$ & $\begin{array}{c}\text { COD } \\
(\mathrm{mg} / \mathrm{L})\end{array}$ & $\begin{array}{c}\text { Removal } \\
\text { COD } \\
(\%)\end{array}$ \\
\hline 2.5 & 8.6 & 7.1 & 80.00 & 82.70 \\
\hline 5 & 8.0 & 7.0 & 80.00 & 82.70 \\
\hline 7.5 & 8.8 & 6.9 & 73.65 & 84.07 \\
\hline 10 & 8.9 & 6.4 & 78.40 & 83.05 \\
\hline 15 & 9.8 & 7.4 & 120.45 & 73.95 \\
\hline 30 & 9.6 & 9.3 & 136.46 & 70.49 \\
\hline 45 & 8.9 & 4.7 & 144.48 & 68.76 \\
\hline 60 & 9.4 & 6.8 & 200.64 & 56.61 \\
\hline 75 & 9.3 & 8.3 & 144.00 & 68.86 \\
\hline 90 & 10.2 & 13.2 & 128.00 & 72.32 \\
\hline
\end{tabular}

\section{The Effect of Diatomite Adsorption on the Removal of} $C O D$ and $S S$

After the three times coagulation, the removal rate of SS, turbidity and COD were more than $90 \%$, but the rest of COD was $73.65 \mathrm{mg} / \mathrm{L}$, still beyond the discharge standard. Therefore, experiment of adsorption treatment was further to be done continually. The diatomite was chosen as absorbent and took the supernatant (COD was $86.4 \mathrm{mg} / \mathrm{L}$ ) after coagulation $50 \mathrm{~mL}$, the $\mathrm{pH}$ value was adjusted to 5.6,6.4,6.9,7.6,8.4 and 10.0 respectively[10]. 5g absorbent was added to each of the supernatant. Absorption results. Thus the optimum $\mathrm{pH}$ was 6.4.

$50 \mathrm{~mL}$ supernatant (COD was $86.4 \mathrm{mg} / \mathrm{L})$ after coagulation was taken, the $\mathrm{pH}$ value was adjusted to 6.4 , and then the different dosages of absorbent was added to the supernatant. Under the condition that optimal $\mathrm{pH}$ value of 6.4, the COD removal rate increased with the increasing of 
the dosages of diatomite. When the dosage of diatomite was $1 \mathrm{~g}$, the removal rate was the highest. If the dosage increased continually, the removal rate of COD decreased (fig.3). Thus the optimum dosage of diatomite was $20 \mathrm{~g} / \mathrm{L}$. The COD of the supernatant after absorbing was $16.18 \mathrm{mg} / \mathrm{L}$, and the removal rate of COD was $80.56 \%$, reaching the Integrated Wastewater Discharge Standard.

\section{CONCLUSIONS AND SUGGESTION}

The comparison showed that aluminum sulfate was the suitable coagulant, and the dosages of three times coagulation were $56.7 \mathrm{mg} / \mathrm{L}, \quad 16 \mathrm{mg} / \mathrm{L}$ and $7.5 \mathrm{mg} / \mathrm{L}$ respectively. The supernatant obtaining after treating the artificial stone wastewater with coagulation, contained the $\mathrm{SS}$ with the concentration of $8.8 \mathrm{mg} / \mathrm{L}$, the turbidity with the concentration of $6.9 \mathrm{NTU}$, the COD with the concentration of $73.65 \mathrm{mg} / \mathrm{L}$, the supernatant after coagulation met the secondary standard number in GB8978-1996. When the $\mathrm{pH}$ was 6.4 and the dosage was $20 \mathrm{~g} / \mathrm{L}$, diatomite as the absorbent treated the supernatant obtained after the coagulation with adsorbing. The COD could decrease to $16.8 \mathrm{mg} / \mathrm{L}$ reaching the primary standard number $\mathrm{A}$ level (COD was $50 \mathrm{mg} / \mathrm{L})$. At last, it could be used for production directly.

\section{ACKNOWLEDGMENT}

This work is supported by the Guangxi Science and Technology Project, Guike Gong 14124004-5-5 the research of resource treatment technology of heavy metal wastewater in mining industry-taking electrolyzed zinc rinse wastewater as sample, Guangxi Science Research and Technology Development Project (Guike 1599005-2-2) based on ditch- pond System of strengthening the rural ecological environment research and demonstration projects. National Natural Science Foundation of China (NO. 41662005)

\section{REFERENCES}

[1] Yong Li, Guofeng Li, Hui Yan. The treatment of wastewater in stone industry.Stone,2016,05:32-34 (in Chinese).

[2] Anonymous. Environmental Research; Reports from Afyon Kocatepe University advance knowledge in environmental research. Ecology, Environment and amp; Conservation, 2009.

[3] Minghui Xie. Discussion about the countermeasures of pollution control in Stone Industry. Environmental Management, 2007, 06:6364 (in Chinese).

[4] Shaohua Feng. Practical technology for wastewater treatment in stone slab processing. China Water and Wastewater, 2010, 14:109-112 (in Chinese)

[5] Xiongping Lin. Analysis on the recycling method about the treatment of wastewater in stone industry. Chemical Engineering and Equipment, 2009, 05:191-192 (in Chinese).

[6] Weixun Chen, Yanhong Chen, Jiyu Zhang. The study of granite processing wastewater flocculation treatment technology. Environmental Engineering,2011,01:46-50 (in Chinese).

[7] Yunfeng Zhang, Meilin Huang, Xiuzhen Xu. Discussion on treatment method of wastewater from stone processing. Energy and Environment, 2011, 05:84-85 (in Chinese).

[8] Bo Xu. Example of treatment engineering on Stone wastewater. Techniques and Equipment for Environmental Pollution Control,2003,08:81-83 (in Chinese).

[9] Liming Cai, Kaihan Chen, Xiaoshuang Hong, Tingfei Wang. Study on lime demulsification/brine flocculation process for wastewater treatment in stone industry. Industrial Water Treatment, 2012, 02:5155 (in Chinese).

[10] Shaoying Guo. Advanced treatment on tail water from municipal wastewater treatment plant by modified diatomite. Master Dissertation, Fujian Normal University, 2010 (in Chinese). 